\title{
Nonomuraea antimicrobica sp. nov., an endophytic actinomycete isolated from a leaf of Maytenus austroyunnanensis
}

\author{
Sheng Oin, ${ }^{1}$ Guo-Zhen Zhao, ${ }^{1}$ Hans-Peter Klenk, ${ }^{2}$ Jie Li, ${ }^{1}$ \\ Wen-Yong Zhu, ${ }^{1} \mathrm{Li}-\mathrm{Hua} \mathrm{Xu}^{1}$ and Wen-Jun $\mathrm{Li}^{1}$ \\ ${ }^{1}$ The Key Laboratory for Microbial Resources of the Ministry of Education, and Laboratory for \\ Conservation and Utilization of Bio-Resources, Yunnan Institute of Microbiology, Yunnan \\ University, Kunming 650091, PR China \\ ${ }^{2} \mathrm{DSMZ}$ - Deutsche Sammlung von Mikroorganismen und Zellkulturen GmbH, Inhoffenstraße 7b, \\ D-38124 Braunschweig, Germany
}

Correspondence

Wen-Jun Li

wjli@ynu.edu.cn or

liact@hotmail.com

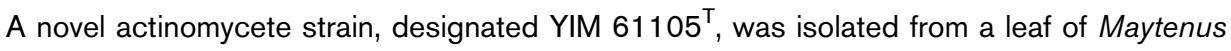
austroyunnanensis from the tropical rainforest in Xishuangbanna, Yunnan Province, south-west China. A 16S rRNA gene sequence analysis revealed that the organism belonged to the phylogenetic cluster of the genus Nonomuraea and was most closely related to Nonomuraea candida HMC10' (98.2\%), 'Nonomuraea aegyptia' S136 (97.9\%), Nonomuraea kuesteri GW $14-1925^{\top}(97.5 \%)$ and Nonomuraea turkmeniaca DSM $43926^{\top}(97.4 \%)$. The $16 \mathrm{~S}$ rRNA gene sequence similarities to other Nonomuraea species were less than $97.4 \%$. The main chemotaxonomic properties of strain YIM $61105^{\top}$, such as the principal amino acid of the peptidoglycan, the predominant menaquinone and the polar lipid profile, supported its classification within the genus Nonomuraea. Strain YIM $61105^{\top}$ was also readily differentiated from closely related species on the basis of a broad range of phenotypic properties and DNADNA hybridization values. Thus, this isolate is considered to represent a novel species of the genus Nonomuraea, for which the name Nonomuraea antimicrobica sp. nov. is proposed. The

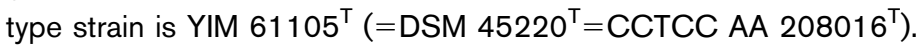

The genus Nonomuraea was proposed by Zhang et al. (1998) as a member of the family Streptosporangiaceae. Members of the genus Nonomuraea are aerobic, Gram-positive, nonacid-fast, non-motile actinomycetes that form an extensively branched substrate and aerial mycelium. The aerial hyphae differentiate into hooked, spiral or straight chains of spores, which show a folded, irregular, smooth or warty ornamentation. The genus is characterized chemotaxonomically by the presence of meso-diaminopimelic acid in the cell wall, madurose as a characteristic sugar in the whole-cell hydrolysates, considerable amounts of $\mathrm{C}_{17: 0}$ 10-methyl and iso- $\mathrm{C}_{16: 0}$ branched-chain fatty acids, major proportions of di-, tetra- and hexahydrogenated menaquinones with nine isoprene units and major amounts of diphosphatidylglycerol, hydroxylated phosphatidylethanolamine, uncharacterized glycolipids and a glucosamine-containing phospholipid (Nonomura \& Ohara, 1971; Zhang et al., 1998; Quintana et al., 2003).

At the time of writing, the genus Nonomuraea comprised 21 species with validly published names and 2 subspecies

The GenBank/EMBL/DDBJ accession number for the 16S rRNA gene sequence of strain YIM $61105^{\top}$ is FJ157184. on the basis of a polyphasic approach. There is no record of the isolation of Nonomuraea species from the endophytic environment. Xishuangbanna is famous in China for its diverse flora, especially the rainforest plants, many of which have an indigenous pharmaceutical history. The rapidly diminishing tropical rainforests may hold the greatest possible resource for acquiring novel microorganisms and their products.

In the course of our study on endophytic actinomycetal diversity of the tropical-rainforest medicinal plants of Xishuangbanna, strain YIM $61105^{\mathrm{T}}$ was isolated from a healthy leaf of Maytenus austroyunnanensis. After being thoroughly washed in tap water, healthy leaf samples were air-dried at room temperature and the surfaces were sterilized according to the five-step sterilization procedure described by Qin et al. (2008). The surface-sterilized samples were pulverized in a ceramic mortar, distributed onto $\mathrm{HV}$ agar (Hayakawa \& Nonomura, 1987) and incubated at $28{ }^{\circ} \mathrm{C}$ for 3 weeks. The isolate was maintained as mycelial fragments in a $20 \%(\mathrm{v} / \mathrm{v})$ glycerol suspension at $-80{ }^{\circ} \mathrm{C}$.

Extraction of genomic DNA and amplification of the 16S rRNA gene sequence from strain YIM $61105^{\mathrm{T}}$ were 
performed as described by Li et al. (2007). An almost-fulllength $16 \mathrm{~S}$ rRNA gene sequence (1454 bp) was aligned with selected sequences obtained from the GenBank/EMBL/ DDBJ databases using CLUSTAL $\mathrm{x}$ version 1.8 (Thompson et al., 1997). Neighbour-joining (Saitou \& Nei, 1987) and maximum-parsimony (Kluge \& Farris, 1969) trees were constructed using MEGA version 3.1 (Kumar et al., 2004). The reliability of the tree topology was evaluated by bootstrap analysis (Felsenstein, 1985). The phylogenetic tree (Fig. 1) based on the 16S rRNA gene sequences revealed that the closest relatives of strain YIM $61105^{\mathrm{T}}$ were Nonomuraea candida $\mathrm{HMC10}^{\mathrm{T}}$ (98.2\%), 'Nonomuraea aegyptia' S136 (97.9\%), Nonomuraea kuesteri GW 14$1925^{\mathrm{T}}(97.5 \%)$ and Nonomuraea turkmeniaca DSM $43926^{\mathrm{T}}$ $(97.4 \%)$. The 16S rRNA gene sequence similarity values between the isolate and other members of the genus Nonomuraea were lower than $97.4 \%$. Strain YIM $61105^{\mathrm{T}}$ formed a coherent and monophyletic clade with ' $N$. aegyptia' S136 that was supported by a high bootstrap value of $84 \%$ in the neighbour-joining tree and also recovered with the maximum-parsimony algorithm.

Cultural and morphological characteristics were observed with strain YIM $61105^{\mathrm{T}}$ grown on yeast extract-malt extract agar (ISP 2), oatmeal agar (ISP 3), inorganic salts-starch agar (ISP 4) and glycerol-asparagine agar (ISP 5; Shirling \& Gottlieb, 1966), as well as potato-glucose agar (PDA; Difco), Czapek's agar and nutrient agar (Waksman, 1967), for 3 weeks at $28{ }^{\circ} \mathrm{C}$. The colour of both substrate and aerial mycelia and any soluble pigments produced were determined by comparison with chips from the colour charts of the Inter-Society Color Council (Kelly, 1964). The morphological features of the spore chains and mycelia were observed by using light microscopy (BH-2; Olympus) and scanning electron microscopy (JSM-5600LV; JEOL). Ranges of conditions required for growth were tested using ISP 2 for $\mathrm{pH} 4.0-11.0$ (at intervals of $0.5 \mathrm{pH}$ units), temperature $\left(0,4,10,15,20,28,37,40,45\right.$ and $\left.55{ }^{\circ} \mathrm{C}\right)$ and $0-20 \%(\mathrm{w} / \mathrm{v}) \mathrm{NaCl}$ (at intervals of $0.5 \%$ ). The ability to use a range of carbon and nitrogen sources for energy and growth and other physiological and biochemical features was tested according to Gordon et al. (1974). Strain YIM $61105^{\mathrm{T}}$ showed good growth on ISP $2-4$ and PDA media, moderate growth on ISP 5 and Czapek's media, and poor growth on nutrient agar. It formed extensively branched substrate mycelia and white-to-pink aerial mycelia on the media tested, and spore chains borne on mycelia were spiral (Fig. 2). Pink diffusible pigments were produced on ISP 5 and PDA media. The physiological and biochemical properties of strain YIM $61105^{\mathrm{T}}$ are listed in Table 1 and the species description.

Biomass for quantitative fatty acid analysis was prepared by scraping colonies from tryptic soy agar (TSA; Difco) after incubation at $28{ }^{\circ} \mathrm{C}$ for 10 days. Biomass for other chemotaxonomic studies was obtained after cultivation at $28{ }^{\circ} \mathrm{C}$ for $7-10$ days in shaken cultures with ISP 2 . The antimicrobial activity of strain YIM $61105^{\mathrm{T}}$ was detected using the agar-well diffusion method (Hugo \& Russell, 1983). Staphylococcus aureus, Escherichia coli, Mycobacterium smegmatis and Candida albicans were used as indicator organisms. Standard analytical procedures were used to extract and analyse the isomeric forms of diaminopimelic acid, whole-organism sugars (Hasegawa et al., 1983), isoprenoid quinones (Groth et al., 1997), polar lipids (Minnikin et al., 1979; Collins \& Jones, 1980) and fatty acids (Sasser, 1990; Kämpfer \& Kroppenstedt, 1996). Strain YIM $61105^{\mathrm{T}}$ contained meso-diaminopimelic

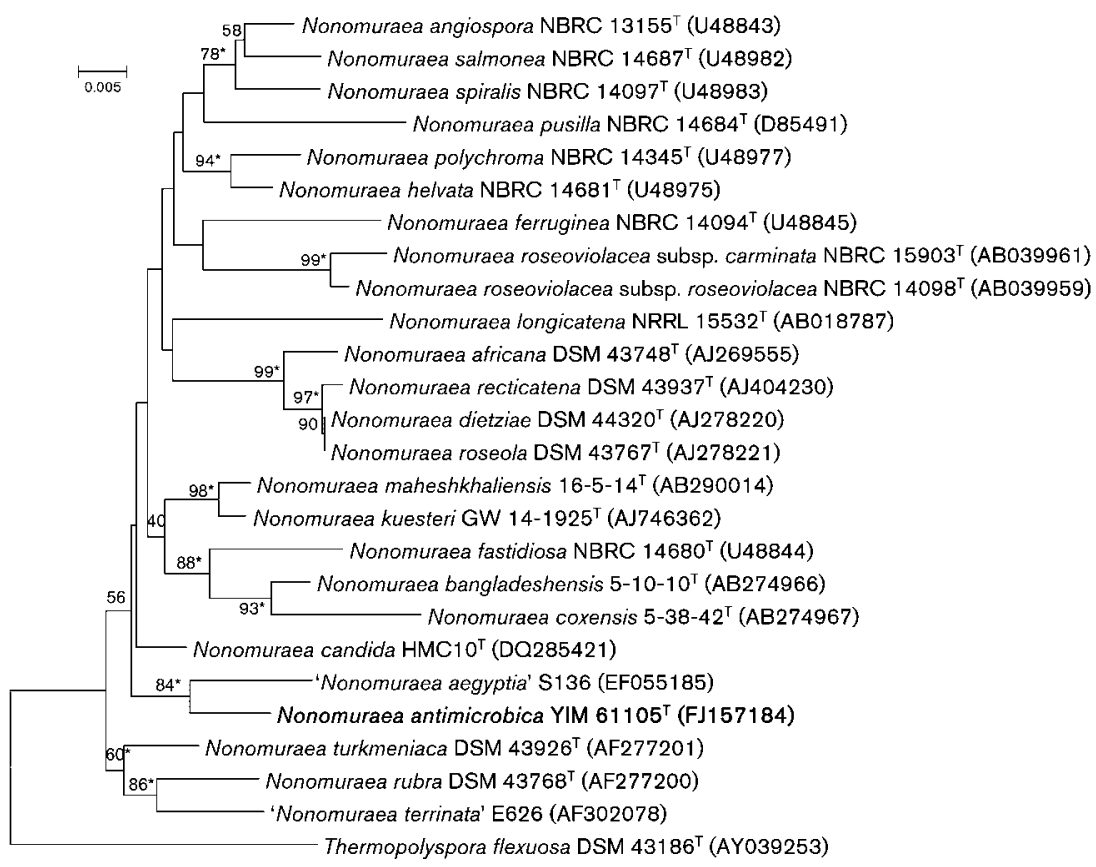

Fig. 1. Neighbour-joining phylogenetic tree based on nearly complete $16 \mathrm{~S}$ rRNA gene sequences showing the relationship between strain YIM $61105^{\top}$ and its phylogenetic neighbours. Percentages at nodes $(>40 \%)$ are levels of bootstrap support based on 1000 resamplings. Asterisks denote nodes that were also recovered using the maximum-parsimony method. Thermopolyspora flexuosa DSM $43186^{\top}$ was used as the outgroup. Bar, 0.005 substitutions per nucleotide position. 


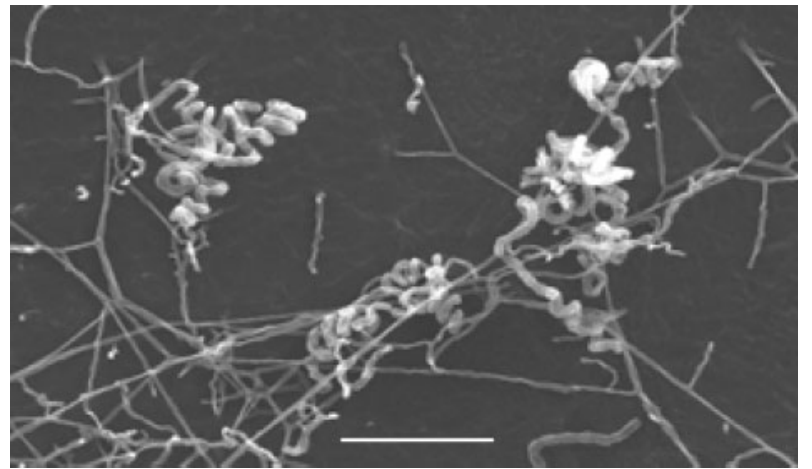

Fig. 2. Scanning electron micrograph of spiral spore chains of strain YIM $61105^{\top}$ after growth on ISP 2 medium at $28^{\circ} \mathrm{C}$ for 3 weeks. Bar, $10 \mu \mathrm{m}$.

acid and madurose in whole-organism hydrolysates (cellwall chemotype IIIB; Lechevalier \& Lechevalier, 1970). The predominant menaquinone was $\mathrm{MK}-9\left(\mathrm{H}_{4}\right)(78 \%)$, and MK-9 $\left(\mathrm{H}_{2}\right)$ (10\%), MK-9 $\left(\mathrm{H}_{6}\right)(6 \%)$ and MK-9 (6\%) were also present. The diagnostic phospholipids were phosphatidylethanolamine and a glucosamine-containing phospholipid (phospholipid type IV; Lechevalier et al., 1977). The detailed fatty acid profile was iso- $\mathrm{C}_{14: 0}(3.9 \%), \mathrm{C}_{14: 0}$
(4.2\%), iso- $\mathrm{C}_{15: 0}(6.5 \%)$, iso- $\mathrm{C}_{16: 1} \mathrm{G}(12.7 \%)$, iso- $\mathrm{C}_{16: 0}$ $(32.2 \%), \mathrm{C}_{16: 0}(11.3 \%), \mathrm{C}_{17: 0}$ 10-methyl (17.1\%), anteiso- $\mathrm{C}_{17: 0}(2.7 \%), \mathrm{C}_{17: 0}(2.4 \%), \mathrm{C}_{18: 1} \omega 9 c(3.0 \%)$ and $\mathrm{C}_{18: 0}$ 10-methyl (5.8\%). Strain YIM $661105^{\mathrm{T}}$ showed antimicrobial activity against Candida albicans.

The genomic DNA G $+\mathrm{C}$ content of strain YIM $61105^{\mathrm{T}}$ was $69.2 \mathrm{~mol} \%$, determined by using HPLC (Mesbah et al., 1989). DNA-DNA relatedness values were measured fluorometrically using the microplate hybridization method (Ezaki et al., 1989; He et al., 2005). Strain YIM $61105^{\mathrm{T}}$ showed relatively low DNA-DNA relatedness with N. candida DSM $45086^{\mathrm{T}}$ (37\%) and ' $N$. aegyptia' DSM $45082(34 \%)$. These results are below the $70 \%$ cut-off point recommended for the delineation of genomic species (Stackebrandt \& Goebel, 1994). It has been shown that Nonomuraea species exhibit high 16S rRNA gene sequence similarities (97.7-99.4\%), but low DNA-DNA relatedness values (<70\%) (Fischer et al., 1983; Poscher et al., 1985; Tamura et al., 2000; Kämpfer et al., 2005). Stackebrandt et al. (2001) reported DNA-DNA relatedness values between the type strains of Nonomuraea africana, $N$. dietziae and $N$. recticatena of $45-48 \%$, although these species shared 16S rRNA gene sequence similarities of 98.9-99.8\%. For this reason, DNA-DNA relatedness experiments between strain YIM $61105^{\mathrm{T}}$ and type strains with $16 \mathrm{~S}$ rRNA gene sequence similarities that were less

Table 1. Comparison of the phenotypic properties of strain YIM $61105^{\top}$ and the nearest phylogenetically related species

Strains: 1, YIM $61105^{\mathrm{T}}$ (N. antimicrobica sp. nov.); 2, 'Nonomuraea aegyptia' S136; 3, Nonomuraea candida HMC10 ${ }^{\mathrm{T}}$; 4, Nonomuraea turkmeniaca DSM $43926^{\mathrm{T}}$; 5, Nonomuraea kuesteri GW 14-1925 ${ }^{\mathrm{T}}$. Data were taken from this study and Kämpfer et al. (2005), Hozzein \& Goodfellow (2007) and Roes \& Meyers (2008). +, Positive; -, negative; w, weak; ND, not determined.

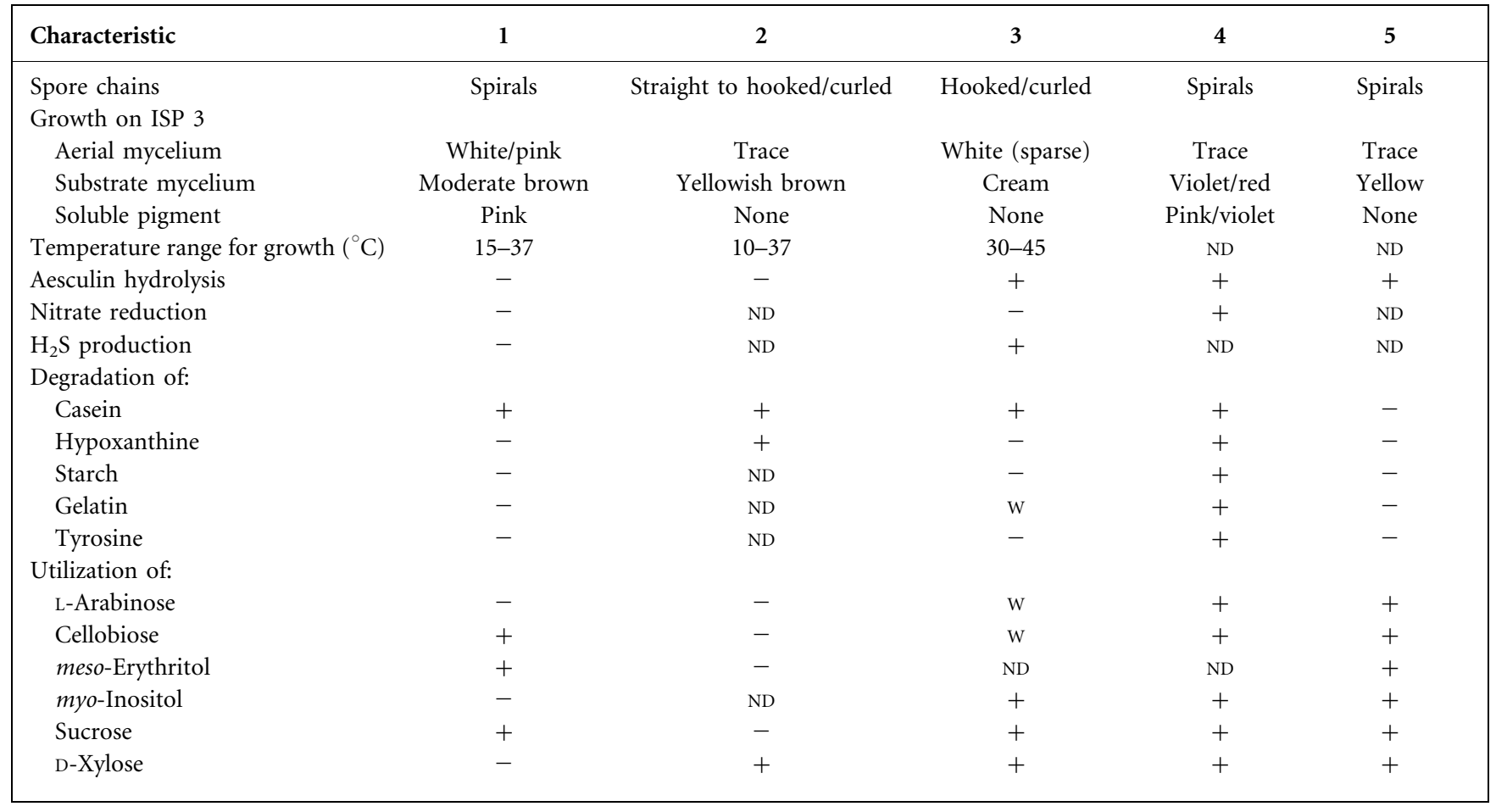


than $97.4 \%$ were not carried out. Recently, Stackebrandt \& Ebers (2006) recommended an increase of about $2 \%$ for the 16S rRNA gene sequence similarity threshold value used to determine the taxonomic status of a strain, from 97 to $98.7-99 \%$, provided that these data are supported by clear phenotypic differences. Thus, strain YIM $61105^{\mathrm{T}}$ clearly represents a novel species in the genus Nonomuraea.

The morphological and chemotaxonomic characteristics of strain YIM $61105^{\mathrm{T}}$ are consistent with its classification in the genus Nonomuraea. However, strain YIM $61105^{\mathrm{T}}$ is phenotypically different from its closest phylogenetic neighbours, with differences, for example, in growth characteristics on ISP 3 medium, spore chain arrangement and biochemical and carbon-source utilization test results (Table 1). On the basis of the phenotypic and genotypic data, strain YIM $61105^{\mathrm{T}}$ represents a novel species within the genus Nonomuraea. In view of its antimicrobial activity towards Candida albicans, the name Nonomuraea antimicrobica sp. nov. is proposed.

\section{Description of Nonomuraea antimicrobica sp. nov.}

Nonomuraea antimicrobica (an.ti.mi.cro'bi.ca. Gr. prep. anti against; N.L. n. microbium microbe; L. adj. suff.-icus - a -um suffix used with various meanings; N.L. fem. adj. antimicrobica antimicrobial).

Gram-positive, aerobic, non-acid-fast and non-acid-alcohol-fast actinomycete that forms extensively branched, brown substrate mycelia and white-to-pink aerial mycelia on ISP $2-5$ and PDA media. Pink diffusible pigments are produced on ISP 5 and PDA media. After 14 days of incubation at $28{ }^{\circ} \mathrm{C}$, spiral spore chains composed of smooth spores are observed on the aerial mycelium. Temperature range for growth is $15-37^{\circ} \mathrm{C}$, with optimal growth at $28{ }^{\circ} \mathrm{C}$. $\mathrm{pH}$ range for growth is $\mathrm{pH}$ 6.0-9.0, with optimal growth at $\mathrm{pH}$ 7.0. No growth is observed with $5 \%$ $\mathrm{NaCl}$. Positive for catalase. Negative for oxidase, milk coagulation, milk peptonization, gelatin liquefaction, cellulose and starch hydrolysis, $\mathrm{H}_{2} \mathrm{~S}$ production and nitrate reduction. The diagnostic amino acid of the peptidoglycan is meso-diaminopimelic acid. Cell hydrolysates contain ribose, glucose, madurose and galactose. Polar lipids include diphosphatidylglycerol, phosphatidylglycerol, phosphatidylinositol and phosphatidylinositol mannosides and the diagnostic phospholipids of phosphatidylethanolamine and an unknown glucosamine-containing phospholipid. The predominant menaquinone of the type strain is MK-9 $\left(\mathrm{H}_{4}\right)$; MK-9 $\left(\mathrm{H}_{2}\right)$, MK-9 $\left(\mathrm{H}_{6}\right)$ and MK-9 are also present. Major fatty acids $(>10 \%)$ are iso- $\mathrm{C}_{16: 0}, \mathrm{C}_{17: 0} 10$ methyl, iso- $\mathrm{C}_{16: 1} \mathrm{G}$ and $\mathrm{C}_{16: 0}$. Additional phenotypic properties are shown in Table 1 . The DNA G $+\mathrm{C}$ content of the type strain is $69.2 \mathrm{~mol} \%$.

The type strain, YIM $61105^{\mathrm{T}}\left(=\mathrm{DSM} 45220^{\mathrm{T}}=\mathrm{CCTCC}\right.$ AA $208016^{\mathrm{T}}$ ), was isolated from a surface-sterilized leaf of Maytenus austroyunnanensis from the tropical rainforest of Xishuangbanna, Yunnan Province, south-west China.

\section{Acknowledgements}

This research was supported by National Basic Research Program of China (project no. 2004CB719601). W.-J.L. was supported by Program for New Century Excellent Talents in University. The authors are indebted to Jing Xiao for the analysis of cellular fatty acids and Yun Chen for determination of DNA G $+\mathrm{C}$ content.

\section{References}

Collins, M. D. \& Jones, D. (1980). Lipids in the classification and identification of coryneform bacteria containing peptidoglycans based on 2,4-diaminobutyric acid. J Appl Bacteriol 48, 459-470.

Ezaki, T., Hashimoto, Y. \& Yabuuchi, E. (1989). Fluorometric deoxyribonucleic acid-deoxyribonucleic acid hybridization in microdilution wells as an alternative to membrane filter hybridization in which radioisotopes are used to determine genetic relatedness among bacterial strains. Int J Syst Bacteriol 39, 224-229.

Felsenstein, J. (1985). Confidence limits on phylogenies: an approach using the bootstrap. Evolution 39, 783-791.

Fischer, A., Kroppenstedt, R. M. \& Stackebrandt, E. (1983). Molecular-genetic and chemotaxonomic studies on Actinomadura and Nocardiopsis. J Gen Microbiol 129, 3433-3446.

Gordon, R. E., Barnett, D. A., Handerhan, J. E. \& Pang, C. H.-N. (1974). Nocardia coeliaca, Nocardia autotrophica, and the nocardin strain. Int J Syst Bacteriol 24, 54-63.

Groth, I., Schumann, P., Rainey, F. A., Martin, K., Schuetze, B. \& Augsten, K. (1997). Demetria terragena gen. nov., sp. nov., a new genus of actinomycetes isolated from compost soil. Int J Syst Bacteriol 47, 1129-1133.

Hasegawa, T., Takizawa, M. \& Tanida, S. (1983). A rapid analysis for chemical grouping of aerobic actinomycetes. J Gen Appl Microbiol 29, 319-322.

Hayakawa, M. \& Nonomura, H. (1987). Humic acid-vitamin agar, a new medium for selective isolation of soil actinomycetes. J Ferment Technol 65, 501-509.

He, L., Li, W., Huang, Y., Wang, L., Liu, Z., Lanoot, B., Vancanneyt, M. \& Swings, J. (2005). Streptomyces jietaisiensis sp. nov., isolated from soil in northern China. Int J Syst Evol Microbiol 55, 1939-1944.

Hozzein, W. N. \& Goodfellow, M. (2007). Nonomuraea aegyptia sp. nov., a novel actinomycete isolated from a sand dune. Antonie Van Leeuwenhoek 92, 165-171.

Hugo, W. B. \& Russell, A. D. (1983). Pharmaceutical Microbiology, 3rd edn. Blackwell: Oxford.

Kämpfer, P. \& Kroppenstedt, R. M. (1996). Numerical analysis of fatty acid patterns of coryneform bacteria and related taxa. Can J Microbiol 42, 989-1005.

Kämpfer, P., Kroppenstedt, R. M. \& Grün-Wollny, I. (2005). Nonomuraea kuesteri sp. nov. Int J Syst Evol Microbiol 55, 847-851.

Kelly, K. L. (1964). Inter-Society Color Council - National Bureau of Standards Color Name Charts Illustrated with Centroid Colors. Washington, DC: US Government Printing Office.

Kluge, A. G. \& Farris, J. S. (1969). Quantitative phyletics and the evolution of anurans. Syst Zool 18, 1-32.

Kumar, S., Tamura, K. \& Nei, M. (2004). MEGA3: integrated software for Molecular Evolutionary Genetics Analysis and sequence alignment. Brief Bioinform 5, 150-163.

Lechevalier, M. P. \& Lechevalier, H. A. (1970). Chemical composition as a criterion in the classification of aerobic actinomycetes. Int J Syst Bacteriol 20, 435-443. 
Lechevalier, M. P., De Bièvre, C. \& Lechevalier, H. A. (1977) Chemotaxonomy of aerobic actinomycetes: phospholipid composition. Biochem Syst Ecol 5, 249-260.

Li, W.-J., Xu, P., Schumann, P., Zhang, Y.-Q., Pukall, R., Xu, L.-H., Stackebrandt, E. \& Jiang, C.-L. (2007). Georgenia ruanii sp. nov., a novel actinobacterium isolated from forest soil in Yunnan (China) and emended description of the genus Georgenia. Int J Syst Evol Microbiol 57, 1424-1428.

Mesbah, M., Premachandran, U. \& Whitman, W. B. (1989). Precise measurement of the $\mathrm{G}+\mathrm{C}$ content of deoxyribonucleic acid by highperformance liquid chromatography. Int J Syst Bacteriol 39, 159-167.

Minnikin, D. E., Collins, M. D. \& Goodfellow, M. (1979). Fatty acid and polar lipid composition in the classification of Cellulomonas, Oerskovia and related taxa. J Appl Bacteriol 47, 87-95.

Nonomura, H. \& Ohara, Y. (1971). Distribution of actinomycetes in soil. XI. Some new species of the genus Actinomadura Lechevalier et al. J Ferment Technol 49, 904-912.

Poscher, J., Kroppenstedt, R. M., Fischer, A. \& Stackebrandt, E. (1985). DNA:DNA reassociation and chemotaxonomic studies on Actinomadura, Microbispora, Microtetraspora, Micropolyspora and Nocardiopsis. Syst Appl Microbiol 6, 264-270.

Qin, S., Wang, H.-B., Chen, H.-H., Zhang, Y.-Q., Jiang, C.-L., Xu, L.-H. \& Li, W.-J. (2008). Glycomyces endophyticus sp. nov., an endophytic actinomycete isolated from the root of Carex baccans Nees. Int J Syst Evol Microbiol 58, 2525-2528.

Quintana, E., Maldonado, L. \& Goodfellow, M. (2003). Nonomuraea terrinata sp. nov., a novel soil actinomycete. Antonie Van Leeuwenhoek 84, 1-6.
Roes, M. L. \& Meyers, P. R. (2008). Nonomuraea candida sp. nov., a new species from South African soil. Antonie Van Leeuwenhoek 93, 133-139.

Saitou, N. \& Nei, M. (1987). The neighbor-joining method: a new method for reconstructing phylogenetic trees. Mol Biol Evol 4, 406-425.

Sasser, M. (1990). Identification of bacteria by gas chromatography of cellular fatty acids, MIDI Technical Note 101. Newark, DE: MIDI Inc.

Shirling, E. B. \& Gottlieb, D. (1966). Methods for characterization of Streptomyces species. Int J Syst Bacteriol 16, 313-340.

Stackebrandt, E. \& Ebers, J. (2006). Taxonomic parameters revisited: tarnished gold standards. Microbiol Today 33, 152-155.

Stackebrandt, E. \& Goebel, B. M. (1994). Taxonomic note: a place for DNA-DNA reassociation and $16 \mathrm{~S}$ rRNA sequence analysis in the present species definition in bacteriology. Int J Syst Bacteriol 44, 846-849.

Stackebrandt, E., Wink, J., Steiner, U. \& Kroppenstedt, R. M. (2001). Nonomuraea dietzii sp. nov. Int J Syst Evol Microbiol 51, 1437-1441.

Tamura, T., Suzuki, S. \& Hatano, K. (2000). Acrocarpospora gen. nov., a new genus of the order Actinomycetales. Int J Syst Evol Microbiol 50, $1163-1171$.

Thompson, J. D., Gibson, T. J., Plewniak, F., Jeanmougin, F. \& Higgins, D. G. (1997). The CLUSTAL_X windows interface: flexible strategies for multiple sequence alignment aided by quality analysis tools. Nucleic Acids Res 25, 4876-4882.

Waksman, S. A. (1967). The Actinomycetes. A Summary of Current Knowledge. New York: Ronald Press.

Zhang, Z. S., Wang, Y. \& Ruan, J. S. (1998). Reclassification of Thermomonospora and Microtetraspora. Int J Syst Bacteriol 48, 411-422. 